\title{
Effect of Physical and Chemical Factors in Production of Alkaline Protease Enzyme by Bacillus Strains
}

\author{
Hamid Tebyanian ${ }^{1,2, a}$, Seyed Hanif Mirhosseiny ${ }^{3, b}$, Afsaneh Bakhtiari ${ }^{4, c}$, \\ Ali Karami ${ }^{1,2, d}$, Sonia Dadseresht ${ }^{5, e}$, Behzad Otroshi ${ }^{6, f^{*}}$ \\ ${ }^{1}$ Research Center for Prevention of Oral and Dental Diseases, Baqiyatallah University of Medical \\ Sciences, Tehran, Iran. \\ ${ }^{2}$ Nanobiotechnology Research Center, Baqiyatallah University of Medical Sciences, Tehran, Iran. \\ ${ }^{3}$ Department of Microbiology, Kerman Science and Research Branch, Islamic Azad University, \\ Kerman, Iran. \\ ${ }^{4}$ Medical Faculty, Midwifery Department, Babol University of Medical Sciences, Babol, Iran. \\ ${ }^{5}$ Department of Anatomical Sciences, School of Medical Sciences, Baqiyatallah University, Tehran, \\ Iran \\ ${ }^{6}$ Department of Microbiology, Faculty of Science, Rasht Branch, Islamic Azad University, Gilan, \\ Iran.

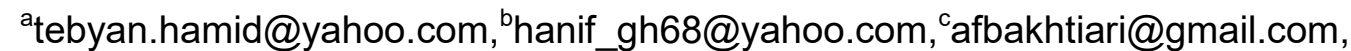 \\ dali.karami@gmail.com, 'edadsereshts2000@gmail.com, 'behzadotroshi@yahoo.com
}

Keywords: Alkaline protease, Bacillus, RSM

\begin{abstract}
Proteases is family of enzymes and it has crucial role due to their physiological roles and very valuable commercial applications. Alkaline protease are produced by Bacillus species are particular importance because of their thermal stability and stability at different $\mathrm{pH}$ values. This study aimed to investigate the effect of physical and chemical factors in production of alkaline protease enzyme fermentation by members of the genus Bacillus. In this study, alkaline protease enzyme production were evaluated in submerged fermentation by Bacillus strains which were isolated from alkaline soils of Guilan province. Factors incubation were optimized such as time, $\mathrm{pH}$, amount of inoculation and ammonium sulfate in alkaline protease enzyme production whit using response surface methodology (RSM) in culture. The maximum enzymatic activity was observed in incubation time of 36 hours, $\mathrm{pH}=9$, inoculation amount of $15 \%(\mathrm{~V})$ and ammonium sulfate $1.5 \%(\mathrm{~W} / \mathrm{V})$. Factors had significant effect on the production of alkaline protease enzyme such as $\mathrm{pH}$ and ammonium sulfate.
\end{abstract}

\section{Introduction}

Proteases are a family of enzymes and they have very an important position because of their physiological and commercial applications. Proteases are physiologically required for living organisms and there are in a wide range of natural sources such as plants, animals and microorganisms. Proteases plays two role of proteolytic and synthetic and their functions have been detected form cell surface to organs and organisms [1,2]. Alkaline proteases are known as ubiquitous in nature. Alkaline proteases are isolated from several sources by surface plating and subsequent screening [3]. Microbial proteases have known as multifunctional enzymes and they can catalyze hydrolysis of proteins to amino acids. Alkaline proteases are the most normally used industrial enzyme among different types of proteases because of high activity and stability [4, 5]. Proteases have numerous commercial applications and among the variety of enzymes, microbial proteases have been used in detergents, pharmaceuticals, industrial enzymes, producing silk and $60 \%$ of total sales of industrial enzymes assigned to this enzyme [1]. Microbial proteases have advantages which are better than a variety of animal and plant resources including: a variety of biochemical, genetic manipulation capabilities, rapid growth, and limited space required for growth $[2,6-10]$. Proteases are categorized according to their source and also, according to the Enzyme 
Commission organization, proteases are class three (hydrolases), and sub-group four (which hydrolyse peptide bonds) [3]. Proteases are divided in 3 types of acidic, neutral and alkaline based on the optimal $\mathrm{pH}$ range. Alkalophilic microorganisms are widely distributed in nature and almost can be found in any environment. However, some specific environments have alkaline substances such as soil, lakes and deserts of alkali. Bacillus have an important role in industry among microorganisms and they are a rich source of alkaline proteases [11-13]. The reaction of protease is affected by some factors, for example $\mathrm{pH}$, ionic strength, Tm and mechanical handling. Novel enzymes constantly are demanded with special properties in the industrial process [3]. The production of this enzyme are performed with both submerged and solid state fermentation culture. Alkaline protease are produced by submerged fermentation and solid state fermentation processes are used less $[8,14,15]$. The $\mathrm{pH}$ of culture disturbs all enzymatic processes and transport of numerous constituents across the cell membrane [3]. $\mathrm{pH}$ should be kept more than 7.5 for increasing the efficiency of protease production during fermentation [8, 14, 15]. This research aimed to optimize the parameters of time, $\mathrm{pH}$, inoculum and ammonium sulfate for producing the alkaline protease by submerged fermentation.

\section{Methods and Materials}

\section{Sample collection and isolation of microorganisms}

15 soil samples were collected from southern areas of Manjil, Lushan and Roodbar (Gilan Province) and transferred in sterile plastic bags to lab. Then, $1 \mathrm{gr}$ of each samples was prepared in $9 \mathrm{ml}$ of distilled water and was heated for 20 minutes at a temperature $80^{\circ} \mathrm{C}$. After that, $0.1 \mathrm{ml}$ of them each was transferred to nutrient agar medium and then, were cultured and incubated for 24 hours at $37^{\circ} \mathrm{C}$. Finally, the colonies were identified by biochemical test [16].

\section{Screening of strains producing enzyme}

All Bacillus strains were cultured in the medium skim milk powder (20 g per liter) and agar (20 g per liter) and was kept at $37^{\circ} \mathrm{C}$ for 24 hours. Producing of a clear halo around the colony represents the protease enzyme production [17].

\section{Identification of strains}

Identification of strains was confirmed by microscopic examination, Gram staining, biochemical tests, Gelatinase experiment, hydrolyzed casein, catalase, hydrolysis of lecithin, urease, decomposition citrate, reduction of nitrate, hydrolyzed starch and sugar fermentation.

\section{Preparation of cultures and Statistics optimization of protease production by RSM}

A source of bacterial inoculation medium was prepared containing glucose (10 g per liter), peptone $(5 \mathrm{~g} \mathrm{~L})$, yeast extract ( $5 \mathrm{~g}$ per liter), casein (2 grams per liter), Di-potassium hydrogen phosphate ( $1 \mathrm{~g}$ per liter), Epsom 7 water $(2.0 \mathrm{~g}$ per liter $)$ per $50 \mathrm{ml}$ were taken and the $\mathrm{pH}$ value of 10 was set using a $\mathrm{pH}$ meter [12]. The efficiency of enzyme production was evaluated by this method. Central composite design includes four independent variables; incubation time (C1), $\mathrm{pH}$ $(\mathrm{C} 2)$, inoculated (C3), the amount of ammonium sulfate (C4) for fermentation in submerged fermentation. 30 tests were designed for submerged fermentation for each factor to zero using these four factors and five levels coded [18].

\section{Determine the accuracy of the response surface model}

Submerged fermentation method was tested experimentally after determining the amount of production (based on software prediction) and the results were compared with predicted results [18].

\section{Optimization of submerged fermentation production by RSM}

The culture medium was prepared containing $50 \mathrm{ml}$ of distilled water and glucose $(10 \mathrm{~g}$ per liter), di-potassium hydrogen phosphate ( $1 \mathrm{~g}$ per liter), magnesium ( 0.2 grams per liter), casein ( $1 \%)$ 
and ammonium sulfate were added in each of 30 experiments and $\mathrm{pH}$ was measured by $\mathrm{pH}$ meter. Then, flasks were sterile for 20 minutes in an autoclave at a temperature $121{ }^{\circ} \mathrm{C}$. The inoculation rate was determined according to table 1 and was added to media. Enzyme production was examined after passing time [19].

\section{The effect of environmental parameters on enzyme production in submerged fermentation}

Culture media were studied in $12,24,36,48,60 \mathrm{~h}, \mathrm{pH}(7,8,9,10,11)$, the inoculation with volume $\%(5,10,15,20,25)$ and ammonium sulfate weights $\%(0.5,1,1.5,2,2.5)$.

\section{Enzyme extraction}

For this purpose, the liquid medium was filtered from filter and poured in test tubes and then, was centrifuged for $20 \mathrm{~min}$ at $6000 \mathrm{rpm}$. The supernatant was used to assess the enzymatic activity as a solution containing the enzyme.

\section{Assessment Activity of enzyme}

The experiment was performed with casein substrate. $200 \mu \mathrm{l}$ of casein substrate solution (containing 20 grams of casein in $1000 \mathrm{ml}$ Tris) were added to $2 \mathrm{ml}$ of enzyme solution and then, incubated for $20 \mathrm{~min}$ at $35 \mathrm{C}^{\circ} .2 / 5 \mathrm{ml}$ TCA (5\% TCA, 9\% and $9 \%$ acetic acid) was added in the solution and held for 5 minutes at room temperature to stop the enzymatic reaction. Then, the tubes were centrifuged for $20 \mathrm{~min}$ at $6000 \mathrm{rpm}$ and then, the optical density of the samples was measured at $280 \mathrm{~nm}$ by a spectrophotometer. A control tube was prepared containing $0 / 2 \mathrm{ml}$ distilled water, $2 \mathrm{ml}$ substrate casein and $2 / 5 \mathrm{ml}$ TCA solution. The effect of $\mathrm{pH}$ was evaluated from $\mathrm{pH} \mathrm{7-11,}$ using sodium phosphate buffer $(\mathrm{pH} 7.0-8.0)$ and glycine $\mathrm{NaOH}(\mathrm{pH} 9.0-11.0)$ buffers. A unit of enzyme activity was defined as the amount of enzyme that can produce one mg tyrosine per minute. The amount of tyrosine results were determined with using standard curve [7].

\section{Statistical analysis}

30 tests were designed by RSM design and analyzed by using the SPSS (ANOVA) software. The level of statistical were considered significant difference $(\mathrm{P}<0.05)$.

\section{Results}

The results of biochemical tests confirmed that this bacteria belonging to Bacillus genus (Table 1). Analysis of variance (ANOVA) showed that $\mathrm{pH}$ and ammonium sulfate have a significant effect on enzyme production $(\mathrm{P}<0.05)$. The maximum amount of enzymes production was in $\mathrm{pH}=9$, inoculation rate of $15 \%$ (volume by volume), ammonium sulfate $1 / 5$ percent (weight by volume) and 36 hours.

Table 1. Biochemical characteristics of the isolated Bacillus

\begin{tabular}{cc}
\hline Biochemical test & Result \\
\hline Hydrolysis of casein & + \\
\hline Hydrolysis of starch & + \\
\hline Hydrolysis of gelatin & + \\
\hline Hydrolysis of lecithin & + \\
\hline Catalase & + \\
\hline nitrate & + \\
\hline Urease & - \\
\hline Analysis of citrate & - \\
\hline movement & + \\
\hline Arabinose & - \\
\hline Maltose & + \\
\hline Mannitol & - \\
\hline Xylose & + \\
\hline
\end{tabular}




\section{Three-dimensional graphs of enzyme production in submerged fermentation by RSM}

The effect of $\mathrm{pH}$ and Ammonium Sulfate was shown in Fig. 1 and Fig. 2 on the production of alkaline protease. Fig. 1 and Fig. 2 show an alkaline protease production. Enzymatic activity was increased in the concentration of ammonium sulfate $1 \%$ with increasing in $\mathrm{pH}$ (range 7 to 9 ) and then it gradually reduced when arriving at the point of maximum $\mathrm{pH}=9$ (the incubation time (36 hours) and inoculation rate (15\% (volume by volume)).

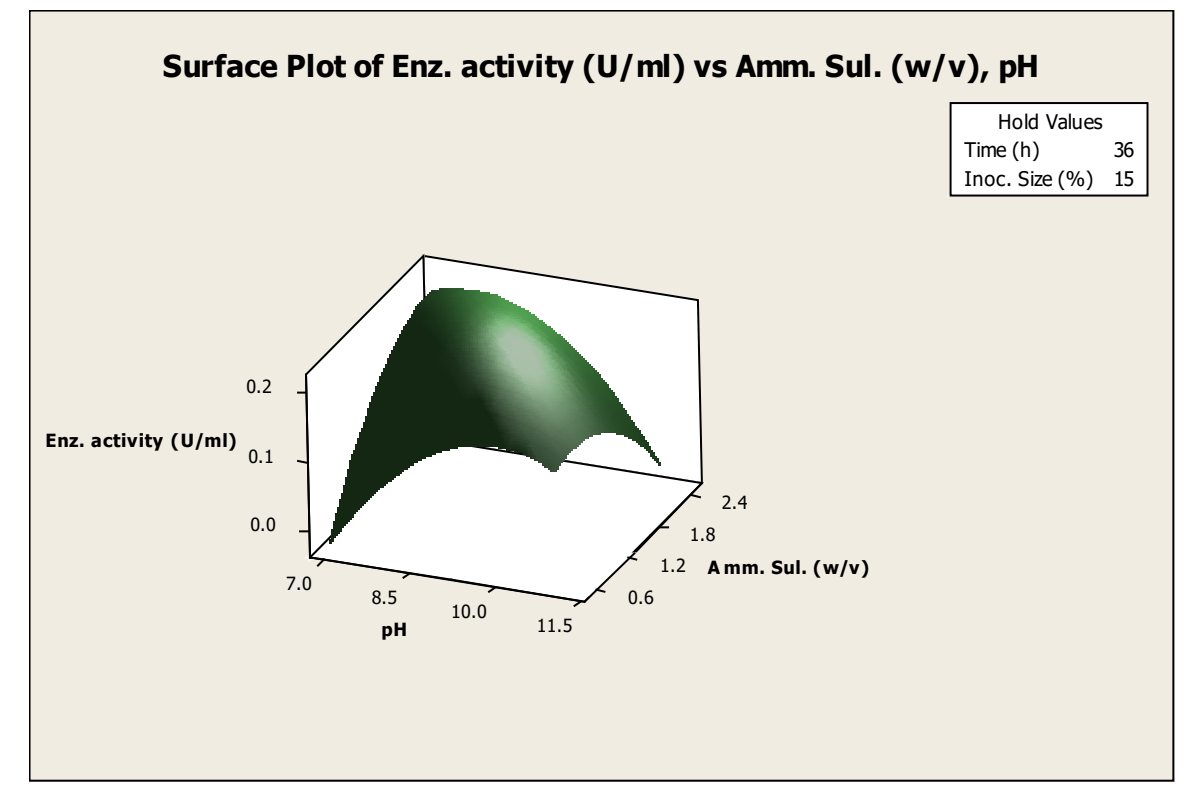

Figure 1. The effect of enzyme activity in the production of alkaline protease by $\mathrm{pH}$ and Ammonium Sulfate

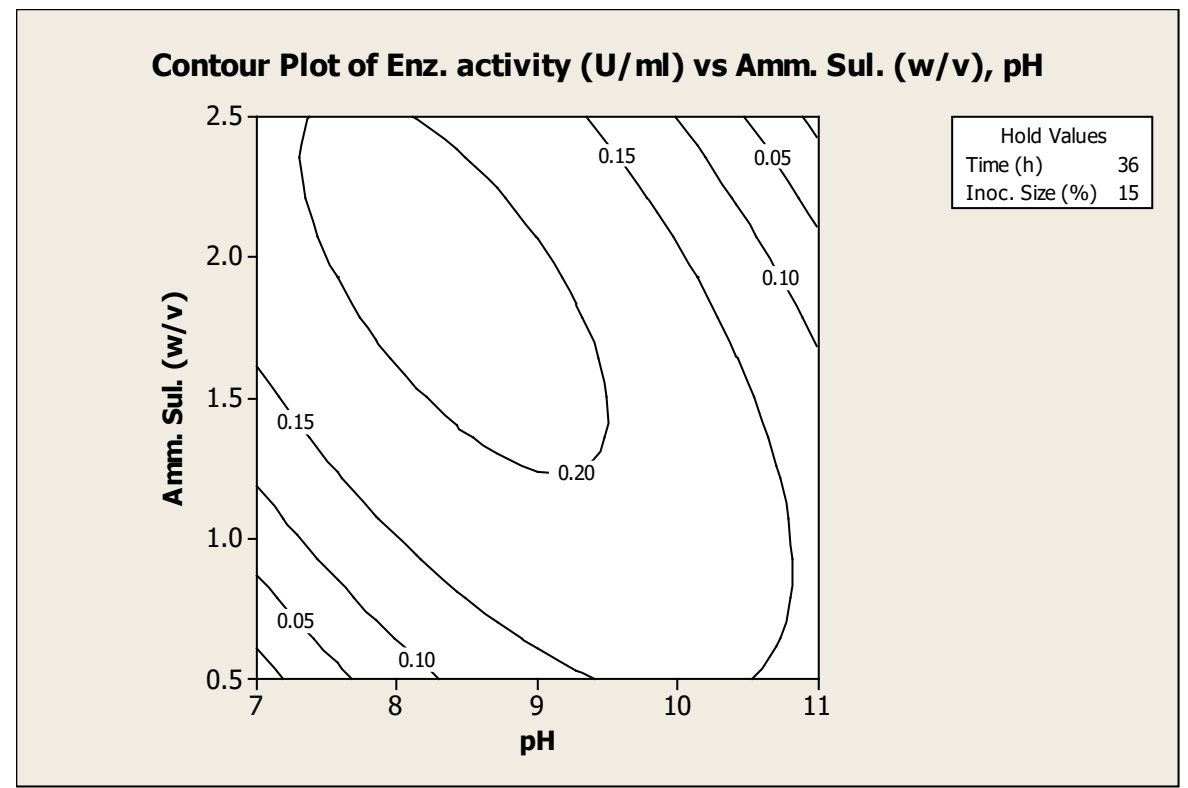

Figure 2. The contour plot of enzyme activity in the production of alkaline protease by $\mathrm{pH}$ and Ammonium Sulfate

\section{Discussion}

Alkaline protease is an important group of enzymes and commercial physiologically as additives in detergents. Biotechnology applications of alkaline protease enzyme have been increased to business goals and also, optimize production medium was suggested for increasing the productivity. Extracellular proteases have numerous applications in various industrial sectors. Although, there are many microbial resources for enzyme production, but few of these resources are 
industrial value [20, 21]. RSM is an experimental design which has advantages over traditional methods. Traditional methods optimization take time and cross-reaction between variables physical and chemical processes cannot be checked. However, RSM can described the incubation time, $\mathrm{pH}$ and the percentage of ammonium sulfate as individual and interaction on alkaline protease production [20]. The best way to determine the effect of independent variables on the dependent variable draws graphs response surface model, which is done by two different variables within the scope of testing and fixing two variables at zero level [20]. According to the obtained results, optimal levels of closed culture was predicted by Minitab 16 software for maximum efficiency of alkaline protease. It predicted time $=37.6970, \mathrm{pH}=8 / 37374$, inoculated $19.3434 \%$ and Sulfate Ammonium 1. 77273 percent for maximum production $(0.329 \mathrm{U} / \mathrm{ml})$. In this research, enzyme activity $\left(\begin{array}{lll}0.318 \mathrm{ml} & \mathrm{U}\end{array}\right)$ was observed that this represents a model of conformity between the predicted results and experimental results. A slight difference between the predicted value and the observed value can be caused by changes in testing conditions. $\mathrm{pH}$ is an important factor in production of alkaline protease enzyme. Changes in enzyme production depends on the $\mathrm{pH}$ value changes. PH conditions vary from one species to another. This change is also seen in different species which isolated from a habitat $[12,22]$.

The results of this research showed that gradually reduce the production of the enzyme were found with increasing the $\mathrm{pH}$ to the optimum value $(\mathrm{pH}=9)$. The increase and decrease in enzyme activity could be due to the effect of $\mathrm{pH}$ on the growth of microorganisms, changes in ionic charge of enzymes and transfer material from membrane [23]. In this study, the maximum production of enzymes was observed in $\mathrm{pH}=9$ which is similar to other researches. Ammonium sulfate was another significant factor. Microorganisms metabolized both organic and inorganic forms of nitrogen to produce amino acids for producing nucleic acids, proteins and cell wall components. Alkaline protease contains nitrogen (15.6 percent) and its production depends on access to sources of carbon and nitrogen in the medium. Although, complex nitrogen source was used for the production of alkaline protease, it requires a suitable nitrogen source depending on the type of organism. Ammonium sulfate is considered as a mineral nitrogen source which is an appropriate source in the production of enzymes [24]. In this study, ammonium sulfate $(0.5,1,1.5,2$ and $2.5) \%(\mathrm{w} v$ ) were studied. Maximum enzyme activity related to experiment with ammonium sulfate $1.5 \%(\mathrm{~W} / \mathrm{V})$. Enzyme activity was $0.160 \mathrm{U} / \mathrm{ml}$ in similar conditions with $0.5 \%$ of ammonium sulfate and reduction of enzyme activity $(0 / 130 \mathrm{U} / \mathrm{ml})$ were obtained with increasing the amounts of ammonium sulfate to $2.5 \%(\mathrm{~W} / \mathrm{V})$. Imtiaz and colleagues in similar studies showed that optimal concentration of nitrogen source to produce varying amounts of alkaline protease enzyme was $1.5 \%$ of ammonium sulfate [24].

Results also showed that enzyme production process was increased by increasing the concentration of inorganic nitrogen to $1.5 \%$ but the production of enzyme was reduced when concentrations was higher than $1.5 \%$. The amount of nitrogen is an essential factor for the enzyme production in the culture medium. Therefore, nitrogen source is critical factor with an appropriate concentration for producing enzyme [24]. Alkaline Protease was produced by Bacillus strains with immersed fermentation method $(36 \mathrm{~h}, \mathrm{pH}=9$, inoculation rate of $15 \%$ (volume by volume) and ammonium sulfate $1.5 \%$ ) and also, $\mathrm{pH}$ and ammonium sulfate had significant effect in production of alkaline protease.

\section{Conclusion}

It can be concluded that time, $\mathrm{pH}$, amount of inoculation and ammonium sulfate had important effects on the production of alkaline protease enzyme which The maximum enzymatic activity was detected in incubation time of 36 hours, $\mathrm{pH}=9$, inoculation amount of $15 \%(\mathrm{~V})$ and ammonium sulfate $1.5 \%(\mathrm{~W} / \mathrm{V})$. 


\section{Acknowledgements}

This study is extracted from Ms.c thesis which has been approved by Department of Microbiology, Faculty of Science, Rasht Branch, Islamic Azad University, Gilan, Iran.

\section{Conflict of Interest}

The authors declare that there is no conflict of interest.

\section{References}

[1] J. Singh, N. Batra, R.C. Sobti, Serine alkaline protease from a newly isolated Bacillus $s p$. SSR1, Process. Chem. 36(8) (2001) 781-785.

[2] S.-L. Wang et al., Two novel surfactant-stable alkaline proteases from Vibrio fluvialis TKU005 and their applications, Enzyme Microb. Technol. 40(5) (2007) 1213-1220.

[3] K.M. Sharma et al., Microbial alkaline proteases: Optimization of production parameters and their properties, Genet. Eng. Biotechnol. J. 15(1) (2017) 115-126.

[4] S. Guleria et al., Purification and characterization of detergent stable alkaline protease from Bacillus amyloliquefaciens SP1 isolated from apple rhizosphere, J. Basic Microbiol. 56(2) (2015) 138-152.

[5] M. Baweja et al., An alkaline protease from Bacillus pumilus MP 27: Functional analysis of its binding model toward its applications as detergent additive, Front. Microbiol. 7 (2016) 1195.

[6] H. Tebyanian et al., Antimicrobial activity of some Lactobacillus species against intestinal pathogenic bacteria, International Letters of Natural Sciences. 65 (2017) 10-15.

[7] F. Uyar, Z. Baysal, Production and optimization of process parameters for alkaline protease production by a newly isolated Bacillus sp. under solid state fermentation, Process. Chem. 39(12) (2004) 1893-1898.

[8] N. Yang et al., Production and purification of protease from a Bacillus subtilis that can deproteinize crustacean wastes, Enzyme Microb Technol. 26(5-6) (2000) 406-413.

[9] H. Yazdi et al., The Effects of some physicochemical stresses on Escherichia coli $\mathrm{O} 157: \mathrm{H} 7$ as clinical pathogenic bacteria, Int. J. Agric. Biol. 18(06) (2016) 1237-1241.

[10] P. Zarparvar et al., Isolation and identification of culturable halophilic bacteria with producing hydrolytic enzyme from Incheh Broun hypersaline wetland in Iran, Cell. Mol. Biol. (Noisy-legrand). 62(12) (2016) 31-36.

[11] N. Bhaskar et al., Partial purification and characterization of protease of Bacillus proteolyticus CFR3001 isolated from fish processing waste and its antibacterial activities, Bioresour. Technol. 98(14) (2007) 2758-2764.

[12] H. Gençkal, Studies on alkaline protease production from Bacillus sp., Master's thesis, İzmir Institute of Technology, 2004.

[13] C.G. Kumar, H. Takagi, Microbial alkaline proteases: from a bioindustrial viewpoint, Biotechnol. Adv. 17(7) (1999) 561-594.

[14] J. Chaloupka, Temperature as a factor regulating the synthesis of microbial enzymes, Microbiol. Sci. 2(3) (1985) 86-90.

[15] S. Ito et al., Enhanced production of extracellular enzymes by mutants of Bacillus that have acquired resistance to vancomycin and ristocetin, Agric. Biol. Chem. 55(9) (1991) 2387-2391. 
[16] H. Tebyanian et al., Isolation and identification of Mycoplasma synoviae from suspected ostriches by polymerase chain reaction, in Kerman Province, Iran, Jundishapur J. Microbiol. 7(9) (2014).

[17] S. Mehrotra et al., The production of alkaline protease by a Bacillus species isolate, Bioresour. Technol. 67(2) (1999) 201-203.

[18] A.K. Mukherjee, S.K. Rai, A statistical approach for the enhanced production of alkaline protease showing fibrinolytic activity from a newly isolated Gram-negative Bacillus $s p$. strain AS-S20-I, N. Biotechnol. 28(2) (2011) 182-189.

[19] C. Sandhya et al., Comparative evaluation of neutral protease production by Aspergillus oryzae in submerged and solid-state ferme ntation, Process. Chem. 40(8) (2005) 2689-2694.

[20] Q.K. Beg, V. Sahai, R. Gupta, Statistical media optimization and alkaline protease production from Bacillus mojavensis in a bioreactor, Process. Chem. 39(2) (2003) 203-209.

[21] A.K. Mukherjee, H. Adhikari, S.K. Rai, Production of alkaline protease by a thermophilic Bacillus subtilis under solid-state fermentation (SSF) condition using Imperata cylindrica grass and potato peel as low-cost medium: Characterization and application of enzyme in detergent formulation, Biochem. Eng. J. 39(2) (2008) 353-361.

[22] H. Genckal, C. Tari, Alkaline protease production from alkalophilic Bacillus sp. isolated from natural habitats, Enzyme Microb. Technol. 39(4) (2006) 703-710.

[23] K.S.B. Naidu, K.L. Devi, Optimization of thermostable alkaline protease production from species of Bacillus using rice bran, Afr. J. Biotechnol. 4(7) (2005) 724-726.

[24] S. Imtiaz, H. Mukhtar, H. Ikram ul, Production of alkaline protease by Bacillus subtilis using solid state fermentation, African Journal of Microbiology Research. 7(16) (2013) 1558-1568. 